\title{
Study the Opinion from the Financial Examination Agency on Regional Government Financial Statements that Obtain Required Opinion with Exceptions (Study in Bengkulu City)
}

\author{
Lawe Anasta
}

\begin{abstract}
The purpose of the study was to analyze and provide descriptions of the things that led to BPK's opinion on the Local Government Financial Statements (LKPD) in the Districts and Cities in Bengkulu Province. This study uses secondary data sources obtained from the Republic of Indonesia BPK headquarters. The theory used in this study is the theory of judgment. The results showed that the Fair With Exception opinion from the Republic of Indonesia BPK was given to the LKPD of Rejang Lebong Regency and the City of Bengkulu, due to the findings of the SPI ineffectiveness with the highest findings, namely, the weakness of the control system in implementing the revenue and expenditure budget. Non-compliance with applicable legislation is found in cases of regional losses, potential regional losses, lack of acceptance, inequality, administrative inefficiency and ineffectiveness. Several cases were found which indicated a discrepancy between the LKPD of Rejang Lebong Regency and the City of Bengkulu with SAP, namely a discrepancy with PSAP No. 01 Presentation of Financial Statements, PSAP No. 02, PSAP No.4 CALK, PSAP No.5 Accounting for Inventories, PSAP No.6 Investment, PSAP No.9 Accounting for PSAP Obligations No.10 Correction of errors in the Budget Realization Report and PSAP No. 07 Accounting for Fixed Assets. The cause of the Rejang Lebong District and the City of Bengkulu not yet obtaining a WTP opinion is the weak quality of human resources who run the regional financial cycle. Limited facilities and infrastructure available, previous year recommendations that have not been followed up.
\end{abstract}

Keywords: BPK Opinion Analysis, Local Government Financial Reports.

DOI: $10.7176 /$ RJFA/10-13-08

Publication date:July $31^{\text {st }} 2019$

\section{Introduction}

Law Number 17 of 2003 concerning State Finance in Article 32 mandates that the form and content of the accountability report for the implementation of the APBN / APBD be prepared and presented in accordance with Government Accounting Standards. The government accounting standards are prepared by a Government Accounting Standards Committee that is independent and stipulated by a Government Regulation after first being considered by the Supreme Audit Agency. The regional financial report is basically an assertion or statement from the management of the local government that informs other parties, namely the existing stakeholders about the financial condition of the local government (Mahmudi, in Anasta 2012). Public sector accounting plays an important role in preparing financial reports as an embodiment of public accountability.

Table 1 Developments in Indonesian Opinions

2012-2016 LKPD Total Opinion

\begin{tabular}{cccccccccc}
\hline LKP & & \multicolumn{8}{c}{ Opini } \\
D & WTP & $\%$ & WDP & $\%$ & TW & $\%$ & TMP & $\%$ & Jumlah \\
2012 & 124 & $23 \%$ & 328 & $61 \%$ & 5 & $1 \%$ & 80 & $15 \%$ & 537 \\
2013 & 161 & $30 \%$ & 317 & $59 \%$ & 11 & $2 \%$ & 48 & $9 \%$ & 537 \\
2014 & 252 & $47 \%$ & 247 & $46 \%$ & 5 & $! \%$ & 33 & $6 \%$ & 537 \\
2015 & 311 & $58 \%$ & 194 & $36 \%$ & 5 & $1 \%$ & 27 & $5 \%$ & 537 \\
2016 & 376 & $70 \%$ & 140 & $26 \%$ & 0 & 0 & 21 & $4 \%$ & 537 \\
\hline
\end{tabular}

Government accounting and financial reporting must show the compliance with laws and regulations relating to the implementation of government accounting. According to Choi (2011) the accounting system, funding sources, taxation, political and economic relations, inflation, the level of economic development, education level, and culture are eight environmental elements that can affect accounting. In addition (Choi 2011) states that law and accounting developments can also influence the results of examinations of local government financial statements revealing non-compliance with statutory provisions that result in regional losses, potential regional losses, lack of acceptance, administration, economic inefficiency, and ineffectiveness. 
Table 2 Development of Bengkulu Regency / City Opinion 2012-2016 BPK

\begin{tabular}{|c|c|c|c|c|c|c|}
\hline \multirow[b]{2}{*}{ No } & \multirow[b]{2}{*}{ KET } & \multicolumn{5}{|c|}{ OPINI BPK } \\
\hline & & $\begin{array}{l}\text { Tahun } \\
2012\end{array}$ & $\begin{array}{c}\text { Tahu } \\
\text { n } \\
2013\end{array}$ & $\begin{array}{c}\text { Tahu } \\
\text { n } \\
2014\end{array}$ & $\begin{array}{c}\text { Tahu } \\
n \\
2015\end{array}$ & $\begin{array}{c}\text { Tahu } \\
n \\
2016\end{array}$ \\
\hline 1 & Prov.Bengkulu & WTP & WTP & WTP & WDP & WDP \\
\hline 2 & $\begin{array}{l}\text { Kab.Bengkulu } \\
\text { Selatan }\end{array}$ & WDP & WDP & WTP & WDP & WDP \\
\hline 3 & $\begin{array}{l}\text { Kab. Bengkulu } \\
\text { Tengah }\end{array}$ & WTP & WTP & WTP & WTP & WDP \\
\hline 4 & Kab. Bengkulu Utara & WTP & WTP & WTP & WDP & WDP \\
\hline 5 & Kab. Kaur & WTP & WTP & WTP & WDP & WDP \\
\hline 6 & Kab. Kepahiang & WDP & WDP & WDP & WTP & WDP \\
\hline 7 & Kab. Lebong & $\begin{array}{l}\text { WTP } \\
\text { DPP }\end{array}$ & WTP & WDP & WTP & WDP \\
\hline 8 & Kab. Mukor & WTP & WTP & WDP & WDP & WDP \\
\hline 9 & Lebong & WDP & WDP & WDP & WDP & WDP \\
\hline 10 & Kab. Seluma & WDP & WDP & TW & WDP & WDP \\
\hline 11 & $\begin{array}{l}\text { Kota Bengkulu } \\
\text { LKPD }\end{array}$ & $\begin{array}{c}\text { WDP } \\
11\end{array}$ & $\begin{array}{l}\text { WDP } \\
11\end{array}$ & $\begin{array}{l}\text { WDP } \\
11\end{array}$ & $\begin{array}{l}\text { WDP } \\
11\end{array}$ & $\begin{array}{c}\text { WDP } \\
11\end{array}$ \\
\hline
\end{tabular}

Formulation of this research problem are:

How does the BPK provide opinions on the Bengkulu City Regional Government Financial Report (LKPD) in terms of the Effectiveness of the Internal Control System?

How the BPK provides opinions on the Bengkulu City Financial Statements (LKPD) in terms of Compliance applicable laws and regulations?

How does the BPK provide opinions on the Bengkulu City Financial Statements (LKPD) in terms of Government Accounting Standards (SAP)?

Why has the City of Bengkulu never received WTP opinion from the BPK until 2016?

\section{Literature review}

Government Accounting Standards (SAP) Government Accounting Standards are accounting principles applied in compiling and presenting government financial reports ". SAP is applied in the scope of government, namely the central government, regional government, and organizational units within the central / regional government if according to the laws and regulations the said organizational unit is obliged to present financial statements. Meanwhile, to overcome the technical problems of the application of PSAP and / or IPSAP, the Government Accounting Standards Committee (KSAP) also publishes the SAP Technical Bulletin. SAP Technical Bulletin contains information that explains accounting techniques as a guideline for users.

\section{Financial statements}

Public Sector Financial Reports In reporting, there are two parties who are considered as the main parties of financial report users, namely internal parties and external parties. For external parties, non-profit institutions including public organizations must report Financial Position, Activity Reports, Cash Flow and Notes to Financial Statements.

Auditing

Understanding audit is a systematic process to obtain and evaluate evidence objectively about statements about activities and economic occurrences, with the aim of determining the level of conformity between these statements with the criteria that have been set, and the delivery of results to interested users (Mulyadi in Novalita 2013: 9). Government Internal Control System (SPIP) 
The Internal Control System (SPI) according to PP No. 60 of 2008 is an integral process in the actions and activities carried out continuously by the leadership and all employees to provide adequate confidence in achieving organizational goals through effective and efficient activities, reliability of financial reporting, security state assets, and compliance with laws and regulations.

Logical Framework

Measurements to obtain a Unqualified Opinion (WTP) financial report must be in accordance with the legislation that has been set. Mardiasmo (2005) argues that audit (audit) is an activity carried out by parties that have competence and independence to check whether the results of government performance are in accordance with established standards.

Research methods

Types of research is descriptive research, namely research conducted to find out and explain the characteristics of the variables studied in a situation (Sekaran, 2006: 58).

Types and Data Sources

This study uses quantitative data and qualitative data. Quantitative data, namely data that can be measured and in the form of numbers. In addition to quantitative data, qualitative data is also used as a complementary element. Qualitative data, namely data in the form of sentences or problem descriptions for existing data. Qualitative data used in this study is data that refers to matters that influence the provision of opinion on the LKPD.

Data collection technique

Secondary data in this study were obtained through document research data collection techniques. Document analysis or content analysis is a method that includes collecting data and information through testing archives and documents (Umar, 2003: 57). Secondary data was obtained from the Republic of Indonesia Supreme Audit Agency in the form of Examination Report (LHP) on District and City Local Government Financial Reports (LKPD) in Bengkulu in 2012-2016.

Data analysis technique

Data analysis is the process of arranging the sequence of data, organizing it into a pattern, category, and basic description unit (Moleong, 2002: 103). Data analysis is an important step in determining the course of the research process. This is because the analysis of data aims to simplify the data that has been obtained into a form that is easier to read or interpret so that it is easy to understand the meaning of the data that has been obtained. The data analysis technique used in this study is qualitative analysis. Qualitative analysis is an analysis of data by providing explanations with sentences to explain data that is not analyzed quantitatively.

Results and Discussion Data Collection Results

Implementation of the Internal Control System (SPI) In accordance with the State Financial Inspection Standards (SPKN), in examining the Financial Statements of the Bengkulu City Government and Rejang Lebong Regency in Bengkulu Province, the BPK considered the District Government's internal control system. Rejang Lebong in Bengkulu Province to determine inspection procedures with the aim of expressing opinions on financial statements and not intended to provide confidence in the internal control system. 
List of Groups and Types of Findings Weaknesses of SPI Examination of Bengkulu City Government Financial Report 2013-2017 Table 4.1

\begin{tabular}{|c|c|c|c|}
\hline No & Kelompok dan Jenis Temuan & $\begin{array}{l}\text { Jumlah } \\
\text { Kasus }\end{array}$ & $\%$ \\
\hline & Kelemahan Sis tem Pengendalian Akuntansi dan & & \\
\hline $\mathbf{I}$ & Pelaporan & 28 & 42 \\
\hline 1 & Pencatatan tidak/belum dilakukan atau tidak akurat. & 6 & \\
\hline 2 & Proses penyusunan laporan tidak sesuai dengan ketentuan. & 6 & \\
\hline 3 & Entitas terlambat menyampaikan laporan. & 2 & \\
\hline 4 & $\begin{array}{l}\text { Sistem informasi akuntansi dan pelaporan tidak memadai. } \\
\text { Sistem informasi akuntansi dan pelaporan belum didukung }\end{array}$ & 13 & \\
\hline 5 & SDM yang memadai. & 1 & \\
\hline II & $\begin{array}{l}\text { Kelemahan sistem pengendalian pelaksanaan anggaran } \\
\text { pendapatan dan belanja }\end{array}$ & 35 & 51 \\
\hline 1 & $\begin{array}{l}\text { Perencanaan kegiatan tidak memadai. } \\
\text { Mekanisme pemungutan, penyetoran dan pelaporan serta }\end{array}$ & 1 & \\
\hline 2 & $\begin{array}{l}\text { penggunaan penerimaan Negara dan hibah tidak sesuai dengan } \\
\text { ketentuan. }\end{array}$ & 6 & \\
\hline 3 & $\begin{array}{l}\text { Penyimpangan terhadap peraturan perundang-undangan bidang } \\
\text { teknis tertentu atau ketentuan intern organisasi yang diperiksa } \\
\text { tentang pendapatan dan belanja. }\end{array}$ & 4 & \\
\hline 4 & Pelaksanaan belanja di luar mekanisme APBD. & 1 & \\
\hline 5 & $\begin{array}{l}\text { Penetapan/pelaksanaan kebijakan tidak tepat atau belum } \\
\text { dilakukan berakibat hilangnya potensi penerimaan/pendapatan. }\end{array}$ & 0 & \\
\hline 6 & $\begin{array}{l}\text { Penetapan/pelaksanaan kebijakan tidak tepat atau belum } \\
\text { dilakukan berakibat peningkatan biaya/belanja. }\end{array}$ & 3 & \\
\hline 7 & $\begin{array}{l}\text { Kelemahan pengelolaan fisik aset, barang milik daerah tidak jelas } \\
\text { keberadaannya, dan mekanisme swakelola tidak tertib. }\end{array}$ & 20 & \\
\hline III & Kelemahan s truktur pengendalian intern & 5 & 7 \\
\hline 1 & $\begin{array}{l}\text { Entitas tidak memiliki standard operating procedure (SOP) } \\
\text { yang formal untuk suatu prosedur atkeskeseluruhan prosedur. }\end{array}$ & 5 & \\
\hline 2 & $\begin{array}{l}\text { SOP yang ada pada entitas tidak berjalan secara optimal atau } \\
\text { tidak ditaati. }\end{array}$ & 0 & \\
\hline 3 & $\begin{array}{l}\text { Entitas tidak memiliki satuan pengawas intern. } \\
\text { Satuan pengawas intern yang ada tidak memadai atau tidak }\end{array}$ & 0 & \\
\hline 4 & berjalan optimal. & 0 & \\
\hline 5 & $\begin{array}{l}\text { Tidak ada pemisahan tugas dan fungsi yang memadai. } \\
\text { Total Kelemahan Sistem Pengendalian Intern }\end{array}$ & $\begin{array}{c}0 \\
68\end{array}$ & 100 \\
\hline
\end{tabular}

Based on the table above, it is known that, there is one finding that indicates the weakness of the accounting and reporting control system, which is the finding that several administrative documents for SKPD financial accounting have not been done. 
Table 4.2. List of Groups and Types of Findings Weaknesses of SPI Examination of 2013-2017 Rejang Lebong District Government Financial Statements.

\begin{tabular}{|c|c|c|c|}
\hline No & Kelompok dan Jenis Temuan & $\begin{array}{l}\text { Jumlah } \\
\text { Kasus }\end{array}$ & $\%$ \\
\hline & Kelemahan Sistem Pengendalian Akuntansi dan & 15 & 47 \\
\hline $\mathbf{I}$ & Pelaporan & & \\
\hline 1 & Pencatatan tidak/belum dilakukan atau tidak akurat. & 5 & \\
\hline 2 & Proses penyusunan laporan tidak sesuai dengan ketentuan. & 5 & \\
\hline 3 & Entitas terlambat menyampaikan laporan. & 2 & \\
\hline 4 & Sistem informasi akuntansi dan pelaporan tidak memadai. & 2 & \\
\hline & Sistem informasi akuntansi dan pelaporan belum didukung & 1 & \\
\hline 5 & SDM yang memadai. & & \\
\hline II & $\begin{array}{l}\text { Kelemahan sistem pengendalian pelaksanaan anggaran } \\
\text { pendapatan dan belanja }\end{array}$ & 17 & 53 \\
\hline 1 & Perencanaan kegiatan tidak memadai. & 3 & \\
\hline 2 & $\begin{array}{l}\text { Mekanisme pemungutan, penyetoran dan pelaporan serta } \\
\text { penggunaan penerimaan Negara dan hibah tidak sesuai dengan } \\
\text { ketentuan. }\end{array}$ & 1 & \\
\hline 3 & $\begin{array}{l}\text { teknis tertentu atau ketentuan intern organisasi yang diperiksa } \\
\text { tentang pendapatan dan belanja. }\end{array}$ & 1 & \\
\hline 4 & $\begin{array}{l}\text { Pelaksanaan belanja di luar mekanisme APBD. } \\
\text { Penetapan/pelaksanaan kebijakan tidak tepat atau belum }\end{array}$ & 1 & \\
\hline 5 & dilakukan berakibat hilangnya potensi penerimaan/pendapatan. & & \\
\hline 6 & $\begin{array}{l}\text { Penetapan/pelaksanaan kebijakan tidak tepat atau belum } \\
\text { dilakukan berakibat peningkatan biaya/belanja. }\end{array}$ & 6 & \\
\hline 7 & $\begin{array}{l}\text { Kelemahan pengelolaan fisik aset, barang milik daerah tidak jelas } \\
\text { keberadaannya, dan mekanisme swakelola tidak tertib. }\end{array}$ & 5 & \\
\hline III & Kelemahan struktur pengendalian intern & & \\
\hline 1 & $\begin{array}{l}\text { Entitas tidak memiliki standard operating procedure (SOP) } \\
\text { yang formal untuk suatu prosedur } \\
\text { keseluruhan prosedur. }\end{array}$ & & \\
\hline 2 & $\begin{array}{l}\text { SOP yang ada pada entitas tidak berjalan secara optimal atau } \\
\text { tidak ditaati. }\end{array}$ & & \\
\hline 3 & Entitas tidak memiliki satuan pengawas intern. & & \\
\hline 4 & $\begin{array}{l}\text { Satuan pengawas intern yang ada tidak memadai atau tidak } \\
\text { berjalan optimal. }\end{array}$ & & \\
\hline 5 & $\begin{array}{l}\text { Tidak ada pemisahan tugas dan fungsi yang memadai. } \\
\text { Total Kelemahan Sis tem Pengendalian Intern }\end{array}$ & 32 & 100 \\
\hline
\end{tabular}

Tabel 4.3. LKPD Kota Bengkulu Tahun 2013-2017

\begin{tabular}{clcc}
\hline No & \multicolumn{1}{c}{ Ketidakpatuhan terhadap Ketentuan } & Jumlah & Perundang-undangan \\
& Pelanggaran & $\begin{array}{c}\text { Persentase } \\
(\%)\end{array}$ \\
1 & Kerugian Daerah & 12 & 24 \\
2 & Potensi Kerugian Daerah & 8 & 12 \\
3 & Kekurangan Penerimaan & 3 & 6 \\
4 & Administrasi & 13 & 25 \\
5 & Ketidakhematan & 2 & 4 \\
6 & Ketidakefisienan & 2 & 4 \\
7 & Ketidakefektifan & 13 & 25 \\
& Jumlah & 53 & 100 \\
\hline
\end{tabular}

Sumber: Data Sekunder (diolah)

Based on the results of the BPK's examination of the Bengkulu City LKPD in Bengkulu in 2013-2017, it was found that some non-compliance with applicable legislation resulted in loss, shortage, acceptance, administration 
and ineffectiveness. With the percentage of non-compliance with legislation on administrative findings and ineffectiveness of the law.

Tabel 4.4 LKPD Kabupaten Rejang Lebong Tahun 2013-2017

\begin{tabular}{clcc}
\hline No & \multicolumn{1}{c}{$\begin{array}{c}\text { Ketidakpatuhan terhadap Ketentuan } \\
\text { Perundang-undangan }\end{array}$} & $\begin{array}{c}\text { Jumlah } \\
\text { Pelanggaran }\end{array}$ & $\begin{array}{c}\text { Persentase } \\
(\%)\end{array}$ \\
1 & Kerugian Daerah & 3 & 8 \\
2 & Potensi Kerugian Daerah & 5 & 13 \\
3 & Kekurangan Penerimaan & 2 & 5 \\
4 & Administrasi & 11 & 28 \\
5 & Ketidakhematan & 0 & 0 \\
6 & Ketidakefisienan & 2 & 5 \\
7 & Ketidakefektifan & 16 & 41 \\
& Jumlah & 39 & 100 \\
\hline
\end{tabular}

Sumber: Data Sekunder (diolah)

Based on the results of the BPK's examination of the LKPD of Rejang Lebong Regency in Bengkulu in 2013-2017, it was found that some non-compliance with the applicable legislation resulted in loss, lack, acceptance, administration and ineffectiveness. With the percentage of non-compliance with legislation on the findings of ineffectiveness. Compliance with Government Accounting Standards (SAP) Based on the results of the BPK RI's examination of statutory compliance and SPI from Bengkulu City LKPD and Rejang Lebong District.

Tabel 4.5. Jumlah Pelanggaran LKPD Kota Bengkulu Tahun 2013-2017 terhadap Standar Akuntansi Pemerintah (SAP)

\begin{tabular}{clcc}
\hline & & Jumlah & Persentase \\
No & Peraturan yang Dilanggar & $\begin{array}{c}\text { Pelanggaran } \\
1\end{array}$ & 6 \\
2 & PSAP No. 01 Penyajian Laporan Keuangan & 1 & 6 \\
3 & PSAP No. 02 Laporan Realisasi Anggaran & 1 & 0 \\
4 & PSAP No. 03 Laporan Arus Kas & 0 & 13 \\
5 & PSAP No. 05 Akuntansi Persediaan & 2 & 6 \\
6 & PSAP No. 06 Akuntansi Investasi & 1 & 31 \\
7 & PSAP No. 07 Akuntansi Aset Tetap & 5 & 19 \\
8 & PSAP No. 08 Akuntansi Konstruksi Dalam & 3 & 0 \\
9 & PSAP No. 09 Akuntansi Kewajiban & 0 & 13 \\
10 & PSAP No. 10 Koreksi Kesalahan, Perubahan & 2 & 6 \\
11 & PSAP No. 11 Laporan Keuangan Konsolidasi & 1 & 0 \\
& Total & 0 & $\mathbf{1 0 0}$ \\
\hline
\end{tabular}

Sumber: Data Sekunder (diolah)

Tabel 4.6 Pelanggaran LKPD Kabupaten Rejang Lebong Tahun 2013-2017 terhadap Standar Akuntansi Pemerintah (SAP)

\begin{tabular}{clcc}
\hline No & \multicolumn{1}{c}{$\begin{array}{c}\text { Peraturan yang Dilanggar } \\
\text { Jumlah } \\
1\end{array}$} & $\begin{array}{c}\text { Pelanggaran } \\
(\%)\end{array}$ \\
2 & PSAP No. 01 Penyajian Laporan Keuangan & 1 & 17 \\
3 & PSAP No. 03 Laporan Realisasi Anggaran & & \\
4 & PSAP No. 04 Catatan Atas Laporan Keuangan & & \\
5 & PSAP No. 05 Akuntansi Persediaan & 2 & \\
6 & PSAP No. 06 Akuntansi Investasi & 3 & \\
7 & PSAP No. 07 Akuntansi Aset Tetap & & \\
8 & PSAP No. 08 Akuntansi Konstruksi Dalam & & \\
9 & PSAP No. 09 Akuntansi Kewajiban & & \\
10 & PSAP No. 10 Koreksi Kesalahan, Perubahan & & \\
11 & PSAP No. 11 Laporan Keuangan Konsolidasi & 6 & \\
\hline
\end{tabular}

Sumber: Data Sekunder (diolah) 
Conclusion

Based on the guidelines on the State Financial Examination Standards (SPKN) stipulated by the BPKRI Regulation from the BPK examination found 100 weaknesses in internal control. 92 issues related to non-compliance with statutory provisions and 22 findings related to PSAP, which affected the BPK RI's opinion on Bengkulu City and Rejang Lebong District in Bengkulu which received a Fair Opinion with Exceptions for the 2013-2017 period: The ineffectiveness of SPI is known to be the weakness of the control system for the implementation of the revenue and expenditure budget, which was mostly found in the LHP of Bengkulu City and Lebanese Rejang for the period 2013-2017. Non-compliance with applicable legislation found 15 cases of regional losses, 13 cases that could potentially harm the region, 24 cases of lack of acceptance, 24 cases of administration, 2 cases of inefficiencies, 4 cases of inefficiency and 29 cases of ineffectiveness. Found 16 cases which indicated a discrepancy between the Bengkulu City LKPD and Rejang Lebong Regency with SAP, Recommendations in previous years have been an obstacle in the achievement of WTP opinion due to many irregularities and shortcomings in implementing the recommendations of the Republic of Indonesia BPK.

\section{Reference}

Abdul Halim. (2012). Akuntansi Keuangan Daerah. Salemba Empat : Jakarta.

Anasta, L., \& Iskandar, D. Studi Eksploratif terhadap Opini Laporan Hasil Pemeriksaan Atas Laporan Keuangan Pemerintah Daerah yang Memperoleh Opini Wajar dengan Pengecualian Menggunakan Content Analysis (Studi Kabupaten/kota Se-provinsi Banten Tahun 2010-2014). Profita, 10(1), 156-177.

Atyanta, R. (2010). Analisa Opini BPK Atas Laporan Keuangan. 1-18.

Hasyim, W. (2013). Faktor-Faktor Yang Memengaruhi Auditor Dalam Memberikan Opini Audit . jurnal Universitas Hasanuddin.

Herliansyah Yudhi \& Ilyas Meifida Pengaruh Pengalaman Auditor Terhadap Penggunaan Bukti Tidak Relevan Dalam Auditor Judgment

Keuangan, B. P. (2012-2016). Laporan Hasil Pemeriksaan. Jakarta Pusat: BPK RI.

Mardiasmo. (2011). Akuntansi Sektor Publik. D.I Yogyakarta: ANDI.

Mardiasmo. (2013). Perpajakan: Edisi Revisi. Andi : Yogyakarta.

Moh. Nazir. (2009). Metode Penelitian. Ghalia Indonesia : Jakarta.

Peraturan Menteri Dalam Negeri Nomor 37 Tahun 2014 Tentang Pedoman Penyusunan Anggaran Pendapatan dan Belanja Daerah Tahun Anggran 2015: Jakarta.

Wikipedia. (2016, Oktober 26). Laporan Keuangan. Dipetik 03 30, 2018, dari https://id.wikipedia.org Timur, P. J. (2018, maret 27). Laporan Keuangan. Diambil kembali dari Kinerja: www.jatimprov.go.id RI, B. (2018, April 25). Laporan Tahunan. Retrieved from IHPS: http://bpk.go.id/ 